\title{
Brugada syndrome diagnosed after ventricular fibrillation with anamnesis of fever
}

\author{
František Nehaja, Michal Mokáňna, Juraj Sokolb ${ }^{b}$ Marianna Kubaškovác, \\ Marián Mokáňna, Peter Galajdaa, Peter Mikolajčík ${ }^{d}$
}

a 1st Department of Internal Medicine, Jessenius Faculty of Medicine in Martin, Comenius University in Bratislava, Martin, Slovakia ${ }^{b}$ Department of Haematology and Transfusiology, National Centre of Haemostasis and Thrombosis, Jessenius Faculty of Medicine in Martin, Comenius University in Bratislava, Martin, Slovakia

'Department of Radiology, Jessenius Faculty of Medicine in Martin, Comenius University in Bratislava, Martin, Slovakia

${ }^{d}$ Department of Surgery, Jessenius Faculty of Medicine in Martin, Comenius University in Bratislava, Martin, Slovakia

\section{ARTICLE INFO}

Article history:

Submitted: 9. 1. 2019

Accepted: 28. 5. 2019

Available online: 16. 9. 2019

Klúčové slová:

Horúčka

Implantovatel'ný srdcový

defibrilátor

Komorová fibrilácia

Náhla srdcová smrt'

Syndróm Brugadových

Keywords:

Brugada syndrome

Fever

Implantable cardiac defibrillator

Sudden cardiac death

Ventricular fibrillation

\section{SÚHRN}

Syndróm Brugadových je genetická porucha charakterizovaná komorovými tachyarytmiami, ktoré môžu viest' k zástave srdca, synkope alebo náhlej srdcovej smrti. Tento syndróm je asociovaný s niekol'kými elektrokardiografickými obrazcami, ako sú napríklad elevácie ST v predných prekordiálnych zvodoch a nekompletná blokáda pravého Tawarovho ramienka. Mnoho ludí so syndrómom Brugadových nemá žiadne príznaky, ak áno, môžu sa vyskytnút kedykol'vek a niekedy môžu byt' vyvolané horúčkou, alkoholom alebo dehydratáciou. Implantácia implantovatel'ného srdcového defibrilátora je jediná liečba, ktorá sa osvedčila ako účinná pri liečbe a prevencii náhlej srdcovej smrti u pacientov so syndrómom Brugadových. Uvádzame zriedkavú kazuistiku syndrómu Brugadových, ktorý sa manifestoval komorovou fibriláciou vyvolanou horúčkou.

(c) 2019, ČKS.

\section{ABSTRACT}

Brugada syndrome is a genetic disorder characterized by ventricular tachyarrhythmias that may lead to cardiac arrest, syncope or sudden cardiac death. This syndrome is associated with several electrocardiographic patterns such as ST elevations in the anterior precordial leads and incomplete right bundle branch block. Many people with Brugada syndrome do not have any symptoms if yes, they can occur at any time and are sometimes triggered by high temperature, alcohol or dehydration. The implantation of an automatic implantable cardiac defibrillator is the only treatment proven effective in treating and preventing sudden cardiac death in patients with Brugada syndrome. We present a rare case report of Brugada syndrome induced by fever which was manifested with ventricular fibrillation. 


\section{Introduction}

The syndrome affects between 1 and 30 per 10,000 people, it is 8-10 times more common in males than in females and in people from Asia aged 30-50 years. ${ }^{1}$ It is also known as Lai Tai (Thailand), Bangungot (Philippines), and Pokkuri (Japan) and seems to be the most common cause of natural death in men younger than 50 years in this region. ${ }^{2}$ It is a genetic disorder with alterations in the SCN5A gene (10-30\% cases) and 300 mutations have been described. ${ }^{3,4}$ There could be other genes affected, which can cause a variant of Brugada syndrome, including the genes coding for alpha1- and beta2b-subunits of the L-type calcium channel (CACNA1C and CACNB2), which are thought to cause a syndrome of precordial ST elevation, sudden death, and short QT interval. ${ }^{5,6}$ The most common manifestations is syncope or cardiac arrest, which occur during sleep, but many patients remain asymptomatic. Sudden cardiac death can occur in family history. Approximately in $20 \%$ of patients atrial fibrillation is an associated arrythmia. ${ }^{7}$ This rare syndrome is named after the Spanish cardiologists Pedro and Josep Brugada who described the condition in 1992. ${ }^{8}$

\section{Case report}

A 46-year-old male was hospitalized after successful cardiopulmonary resuscitation. Computed tomography angiography (CTA) and computed tomography scan (CT) of head showed physiological findings. The medical history of the patient was without a serious illness but with an anamnesis of recent common fever and an unexplained syncope. There was no family history of arrhythmias or sudden unexplained death. The 12-lead electrocardiogram showed a sinus rhythm with non-specific changes in ST segment in chest leads. The cardiac specific markers were slightly elevated, coronarography showed no signs of coronary artery disease. Echocardiogram showed normal cardiac structures and function. 24-hour electrocardiogram Holter monitoring revealed multiple runs of asymptomatic non-sustained polymorphic ventricular tachycardia and non-specific ST elevation in chest leads which evoked concern for a Brugada-like pattern. The diagnosis of Brugada syndrome was established based on the characteristic Brugada type 2 electrocardiogram pattern (Fig. 1) in conjunction with ventricular fibrillation documented by emergency medical service. The patient was referred to cardiac centre and an implantable cardioverter defibrillator (ICD) was implanted. The elevated cardiac specific markers were elevated presumably because of the resuscitation and defibrillation. The patient is doing well and his neurological status had a good recovery.

\section{Discussion}

Each syncope should be performed with a 12-lead ECG and interpreted with an experienced physician or elec-

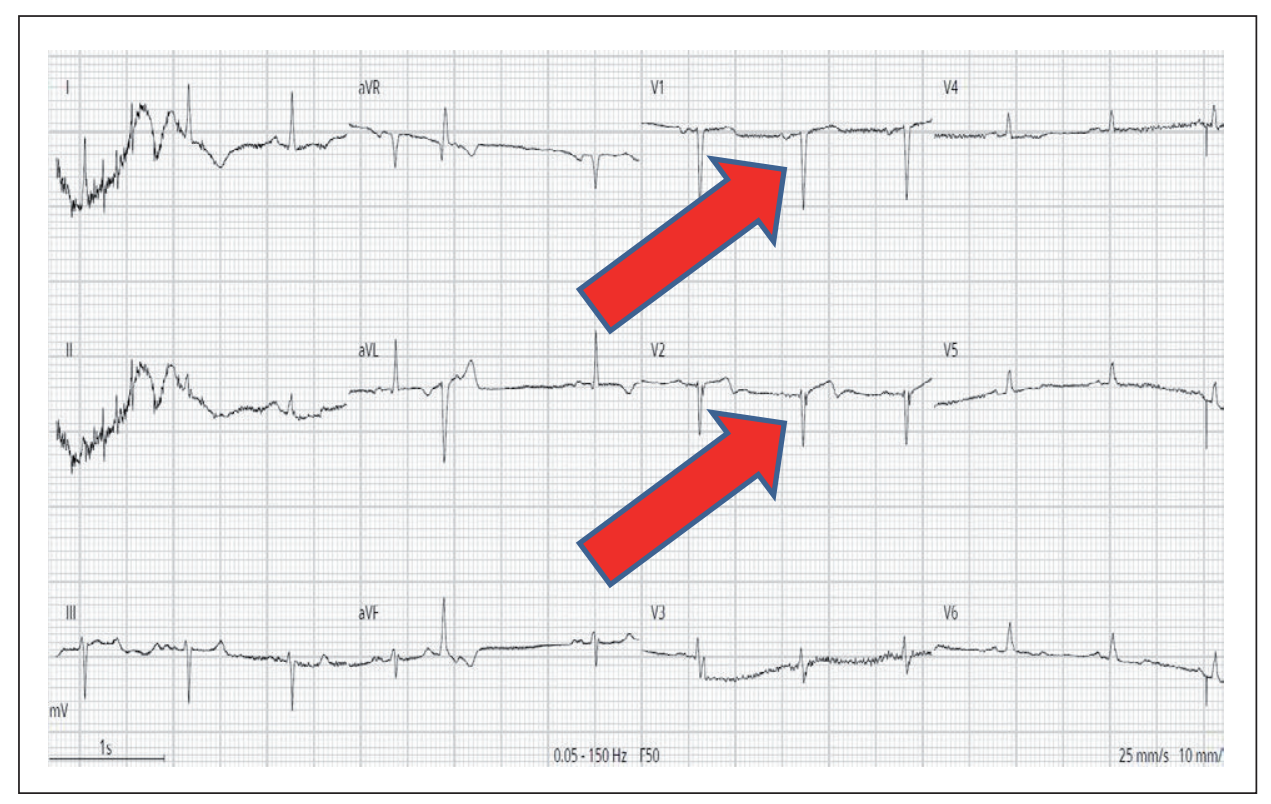

Fig. 1 - Electrocardiogram of a patient with Brugada syndrome

Table 1 - Diagnostic electrocardiogram patterns in Brugada syndrome

\begin{tabular}{l|l|l|l}
\hline Characteristic & Type 1 & Type 2 & Type 3 \\
\hline J wave amplitude & $\geq 2 \mathrm{~mm}$ & $\geq 2 \mathrm{~mm}$ & $\geq 2 \mathrm{~mm}$ \\
\hline T wave & Negative & Positive or biphasic & Positive \\
\hline ST-T configuration & Cove-type & Saddleback & Saddleback \\
\hline ST segment, terminal portion & Gradually descending & Elevated by $\geq 1 \mathrm{~mm}$ & Elevated by $<1 \mathrm{~mm}$ \\
\hline
\end{tabular}


trophysiologist. We should consider diagnostic three ECG patterns for Brugada syndrome (Table 1).,9,10 Hypercalcemia, hyperkalemia and an acute coronary syndrome should be excluded which may have similar pattern on ECG to Brugada syndrome. A febrile state, hypokalemia, alcohol and cocaine intoxication, sodium channel blockers and heterocyclic antidepressants may unmask Brugada syndrome on ECG. Patients should be genetically tested for a mutation in SCN5. Echocardiography or other examinations (MRI) should be performed to exclude arrhythmogenic right ventricular cardiomyopathy, myocardial injury or other cardiomyopathy. In some cases the intravenous administration of drugs that block sodium channels such as flecainide, procainamide, ajmaline and pilsicainide. ${ }^{11}$ This may unmask the Brugada syndrome on ECG and it should be performed with continuous cardiac monitoring and in a setting equipped for resuscitation.

\section{Conclusion}

The Brugada syndrome is a channelopathy caused by an alteration in the transmembrane ion currents that together constitute the cardiac action potential. The exact mechanism underlying the ECG alterations and arrhythmogenesis in Brugada syndrome are not fully understood. Nowadays the only treatment proved effective in treating and preventing sudden death in patients with Brugada syndrome is an implantation of ICD. No pharmacological drugs or treatment have reduced the sudden cardiac death. ${ }^{12}$

\section{Conflict of interest}

The authors declare that there are no conflicts of interest.

\section{Funding body}

The work was supported by grants VEGA 1/0187/17 and APVV-17-0054.

\section{References}

1. Polovina MM, Vukicevic M, Banko B, et al. Brugada syndrome: A general cardiologist's perspective. Eur J Intern Med 2017;44:19-27.

2. Nademanee K, Veerakul G, Nimmannit S, et al. Arrhythmogenic marker for the sudden unexplained death syndrome in Thai men. Circulation 1997;96:2595-2600.

3. Kapplinger JD, Tester DJ, Alders $M$, et al. An international compendium of mutations in the SCN5A-encoded cardiac sodium channel in patients referred for Brugada syndrome genetic testing. Heart Rhythm 2010;7:33-46.

4. Bolek $O$, Marek D, Táborský M. What is new in Brugada syndrome? Cor Vasa 2013;55:e525-e532.

5. Antzelevitch C, Pollevick GD, Cordeiro JM, et al. Loss-offunction mutations in the cardiac calcium channel underlie a new clinical entity characterized by ST-segment elevation, short QT intervals, and sudden cardiac death. Circulation 2007; 115:442-449.

6. Derevjaník M, Šedivá L. Brugada syndrome - Case report, risk stratification and treatment. Cor Vasa 2016;58:e491-e496.

7. Bordachar $P$, Reuter $S$, Garrigue $S$, et al. Incidence, clinical implications and prognosis of atrial arrhythmias in Brugada syndrome. Eur Heart J 2004;25:879-884.

8. Brugada P, Brugada J. Right bundle branch block, persistent ST segment elevation and sudden cardiac death: a distinct clinical and electrocardiographic syndrome. A multicenter report. J Am Coll Cardiol 1992;20:1391-1396.

9. Junttila MJ, Brugada $\mathrm{P}$, Hong K, et al. Differences in 12-lead electrocardiogram between symptomatic and asymptomatic Brugada syndrome patients. J Cardiovasc Electrophysiol 2008;19:380-383.

10. Wilde AA, Antzelevitch C, Borggrefe M, et al. Proposed diagnostic criteria for the Brugada syndrome: consensus report. Circulation 2002;106:2514-2519.

11. Antzelevitch C, Brugada P, Brugada J, Brugada R. Brugada syndrome: from cell to bedside. Curr Probl Cardiol 2005;30:954.

12. Priori SG, Wilde AA, Horie M, et al. HRS/EHRA/APHRS expert consensus statement on the diagnosis and management of patients with inherited primary arrhythmia syndromes: document endorsed by HRS, EHRA, and APHRS in May 2013 and by ACCF, AHA, PACES, and AEPC in June 2013. Heart Rhythm 2013;10:1932-1963. 